\title{
Development of a high-resolution 3D geological model for landfill leachate risk assessment
}

Høyer, A.-S.; Klint, K.E.S.; Fiandaca, G.; Maurya, P.K.; Christiansen, A.V.; Balbarini, N.; Bjerg, P.L.; Hansen, T.B.; Møller, I.

\section{Published in:}

Engineering Geology

Link to article, DOI:

10.1016/j.enggeo.2018.12.015

Publication date:

2019

Document Version

Peer reviewed version

Link back to DTU Orbit

Citation (APA):

Høyer, A-S., Klint, K. E. S., Fiandaca, G., Maurya, P. K., Christiansen, A. V., Balbarini, N., Bjerg, P. L., Hansen, T. B., \& Møller, I. (2019). Development of a high-resolution 3D geological model for landfill leachate risk assessment. Engineering Geology, 249, 45-59. https://doi.org/10.1016/j.enggeo.2018.12.015

\section{General rights}

Copyright and moral rights for the publications made accessible in the public portal are retained by the authors and/or other copyright owners and it is a condition of accessing publications that users recognise and abide by the legal requirements associated with these rights.

- Users may download and print one copy of any publication from the public portal for the purpose of private study or research.

- You may not further distribute the material or use it for any profit-making activity or commercial gain

- You may freely distribute the URL identifying the publication in the public portal 
1 Development of a high-resolution 3D geological model for landfill

2 leachate risk assessment

3 A-S. Høyer ${ }^{\star a}$, K.E.S. Klint ${ }^{b}$, G. Fiandaca ${ }^{c}$, P. K. Mauryac, A. V. Christiansen ${ }^{c}$, N. Balbarini $^{d}$, P. L. Bjerg $^{d}$,

4 T. B. Hansen ${ }^{\mathrm{e}}$, I. Møllera

$5 \quad$ *: corresponding author

6 a: Geological Survey of Denmark and Greenland (GEUS), Aarhus, Denmark

7 b: GEO, Kgs. Lyngby, Denmark

8 c: Aarhus University, Aarhus, Denmark

9 d: Technical University of Denmark (DTU), Kgs. Lyngby, Denmark

10 e: Central Region Denmark, Horsens, Denmark 
Abstract:

Groundwater protection and risk assessment of contaminated sites (e.g. abandoned landfills, industrial waste facilities, gasoline stations, and dry cleaners) situated in complex glacial landscapes are extremely challenging. A common method to assess the risks for leakage and contamination of groundwater and surface water is to develop hydraulic models. However, reliable models need to contain information about both the three-dimensional (3D) distribution of the deposits and their hydraulic properties. Environmental risk assessments therefore require highly detailed digital 3D geological models. In order to construct models with this degree of detail, dense data coverage with high-quality data is necessary. Many studies rely of few data sources, resulting in relatively sparse data.

In this study we demonstrate how 6 different data sources can be combined to gain new insight on the geological history, which is central to the subsequent 3D geological modelling. The analyses in this study include (i) geomorphology, (ii) spear-auger mapping and near-surface electromagnetic induction data, (iii) borehole analyses, (iv) geoelectrical profiling, and (v) transient electromagnetic measurements.

The study area is located on the island of Samsø, in the central part of Denmark, where a digital 3D geological model is constructed. The model consists of combined layer and voxel models and covers a small area $\left(\sim 1 \mathrm{~km}^{2}\right)$ surrounding a former landfill (Pillemark). The near-surface geology is characterized by a deadice landscape formed by glaciers during the Weichselian ice-age. By interpreting the new data it has been possible to update and revise the geological history, which was used during the development of a highly detailed 3D geological model. This model was constructed combining layers and voxels in order to better represent the complex geology and incorporate all the details provided by the different data sources.

The novel geological understanding was used to update the risk assessment of the Pillemark landfill, where a remedial pumping today is on-going. The immediate risk is related to the migration of landfill leachate downgradient through a lacustrine sandy aquifer and wetlands. Groundwater used for drinking water purposes is abstracted from an underlying sand and gravel aquifer (Tebbestrup formation), which is protected by a clay till (mid Danish till) found in the entire Pillemark area. A vertical hydraulic gradient from the upper to the lower aquifer indicates groundwater flow. However, the actual impact of landfill on the deeper aquifer has to be assessed by a detailed evaluation of the drainage system, pumping schemes and groundwater quality in the 
1 area. The 3D geological model is an important step toward the development of a groundwater flow model,

2 required in order to establish a water balance for the hydrogeological system and estimate the vertical 3 transport.

4

$5 \quad$ Keywords: landfill; geomorphology; geophysics; geological modelling; leachate risk assessment 
Abandoned landfill sites with leaching of contaminants pose a risk to groundwater and surface water (Christensen et al., 2001; Milosevic et al., 2012). In order to evaluate the risk for water resources, different risk assessment approaches are available (e.g. Bjerg et al., 2011; Butt et al., 2008). Butt et al. (2016) presented a conceptual framework for a holistic risk assessment of landfills. The fundamental and initial stage of any risk assessment is the baseline study including geology, hydrology, hydrogeology, topography, meteorology, geography, human influences and site management (Butt et al., 2014).

Old landfill sites are often large with complex mixture of municipal waste, demolition waste and specific chemicals. They are typically constructed without any collection of the leachate generated by the infiltrating precipitation and liners to protect the underlying groundwater. Landfills are often placed in former sand, gravel or peat pits, wetlands or waterlogged areas, where former excavations and drainage system complicates the flow field (Christensen et al., 2001; Bjerg et al., 2011). In sandy deposits landfill leachate plumes can be formed posing a risk to downgradient water bodies, while the flow and leaching in low permeability geological settings are much more complex involving heterogeneous flow patterns, matrix diffusion and potentially fracture flow (Chambon et al., 2011; Thomsen et al., 2012).

In complex geological environments, digital 3D geological models (e.g. Kaufmann and Martin, 2008; Lelliott et al., 2006; Robins et al., 2008; Wycisk et al., 2009) are crucial for risk assessment of contaminated sites. In order to evaluate possible contaminant migration, the geological models need to provide detailed information on geological heterogeneity, hydraulic properties, connectivity of layers and aquifer interconnectivity. A prerequisite for constructing geological models, that realistically represent the geological structures, is accessibility to data providing information on these geological structures. Most geological environments are too complex to be modelled based exclusively on $1 \mathrm{D}$ information from boreholes. Thus, information from 2D and 3D geophysical surveys are often needed. Geophysical data have been applied for geological characterization at a wide range of scales during the last decades (e.g. Binley and Kemna, 2005; Loke et al., 2013; Pellerin, 2002) and numerous studies discuss the applicability in glacial environments (e.g. Høyer et al., 2013; Jørgensen et al., 2003; Kristensen et al., 2009) and at landfill sites (e.g. Chambers et al., 2006; Dahlin et al., 2002; Dumont et al., 2017; Dumont et al., 2018; Gazoty et al., 2012b; Guérin et al., 2004; Maio et al., 2018; Ustra et al., 2012). 
Reliable geological interpretations of geophysical data require thorough knowledge of the geological environment. Thus, the first step in geological modelling is the interpretation of the geological environment and the construction of a conceptual geological model. Often, geomorphological information has mainly been used in near-surface studies. However, Klint et al. (2013) introduced a method, referred to as the Poly Morphological (PM) approach, where geomorphology and geology were combined to map superimposed landforms with typical sediment types related. By utilizing these geological observations, it becomes possible to construct more reliable geological models that include the stratigraphical information in a systematic way. Even though the use of different methods for collecting data have been tested at landfill sites with complex geology, only few studies present the combination of the different datasets (e.g. Dumont et al., 2017).

The aim of the paper is to develop a systematic step-wise procedure for producing a highly detailed geological characterization (further details outlined below). This study focuses on an area of c. $1 \mathrm{~km}^{2}$ around the former Pillemark landfill site on the southern part of the island of Samsø in the central part of Denmark. As an important part of the study a new conceptual model of the regional geology of the southern Samsø has been derived. Finally, the new geological understanding made it possible to perform an initial risk assessment of the former landfill site potentially posing a risk to groundwater and surface water in the study area.

The stepwise procedure includes 1) a review of the regional geological and geomorphological settings extracting information from databases and literature, 2) construction of a regional geomorphological map, 3) 2D and 3D geophysical surveying to attain supplementary local information to resolve the details in the geological environment, 4) near-surface mapping combining traditional spear-auger mapping and an electromagnetic induction survey resulting in a detailed and updated geological map, 5) installation of additional boreholes supporting the interpretation of the geophysical data and filling gaps in existing local geological knowledge, 6) sediment analyses for stratigraphic/generic interpretation and characterization of the deposits, 7) unravelling the geological history of the area to obtain a conceptual geological understating of the area and 8) construction of a high-resolution 3D geological model based on the understanding of the geological history and the field data. 


\section{Regional Geology and Geomorphology}

The overall field area covers $1.5 \times 1.5 \mathrm{~km}$ in the central part of Denmark (Fig. 1a) around the former Pillemark landfill site located on southern Samsø (Fig. 1b). To derive a conceptual understanding of the geology, a regional study of the Quaternary deposits for the entirety of southern Sams $\varnothing$ was conducted, allowing the construction of a new geomorphological map for the area (Fig. 1b)
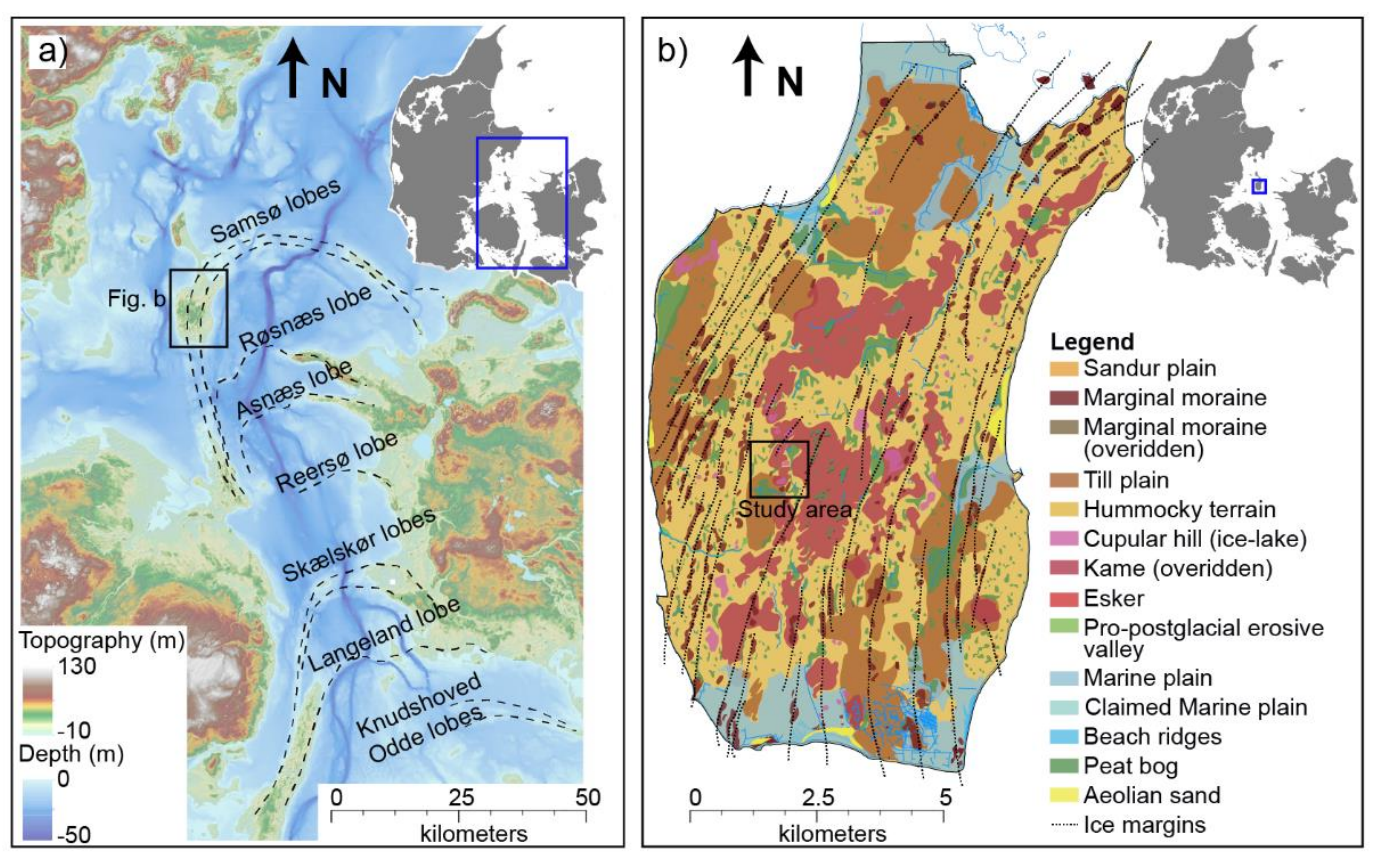

Fig. 1: Geological setting of the study area. a) Topographic map outlining on- and offshore topography in the Great Belt area. The ice margin lobes from periodic minor re-advances during the general retreating Bælthav Ice stream are outlined and named after local areas. b) Geomorphology of Southern Samsø with the characteristic overridden flat-topped kames and the elongated minor marginal hills outlining several minor readvances.

Prior to this study, the geological mapping on Samsø was conducted by Madsen (1897) more than 100 years ago, and this map therefore required updating. However, Madsen's (1897) findings, that the near-surface part of Samsø was covered by two clay tills possibly deposited during the Young Baltic advances in the Weichselian glaciation, are still relevant. Madsen (1897) concluded that the uppermost till was deposited by an ice-stream younger than the ice-stream reaching the East Jutland Ice boarder (19-18,000 BP, HoumarkNielsen (2011)) and hence named it the Bælthav advance (18-17,000 BP). The most comprehensive study of Sams $\varnothing$ was conducted by Houmark-Nielsen (1987), who suggested that the lower till described by Madsen 
1 (1897), should in many places, be ascribed to the so-called Warthe advance in the Saalian glaciation 145150.000 BP (Houmark-Nielsen, 1987). Houmark-Nielsen (1987) argued that the Mid Danish till Formation (Fm.) deposited by the North-Eastern advance (22-20,000 B.P.) is only sparsely found on Samsø. Finally, he concluded that both the East-Jutland till Fm. and the Bælthav till Fm. are widely distributed on Samsø. According to Houmark-Nielsen (2011), the Kattegat till Fm. (deposited by the Kattegat Ice Stream (29-27,000 BP)) is not present on Southern Samsø, thus indicating that the Norwegian Ice advance did not reach this far south.

The geomorphological map, constructed in this study, is shown together with the ice margin lobes in the Great Belt area in Figure 1a and b. The southern Samsø (Fig. 1b) are dominated by distinct glacial landforms primarily formed during the last Young Baltic glaciation in the Weichselian glaciation (19 - 16,000 yr BP) (Houmark-Nielsen et al., 2005). The geology and geomorphology are characterised by clay till plains and hummocky terrain with characteristic dead-ice landscape represented by kames containing both clay till and glaciolacustrine clay, silt and sand (Fig. 1b). On top of this, several distinct, mainly sandy, hills are arranged as elongated pearls on string outlining former marginal moraines (Fig. 1b). These marginal moraines overprint a system of large plateau hills intercalated with local depressions and a generally hummocky appearance (Fig. 1b). At least 13 marginal moraines may be identified on the geomorphological map. These hills are a part of a major system of marginal hills outlining the lobate shape of a major retreating glacier (The Samsø lobes, Fig. 1a). The numerous minor hills on Samsø, that outline the glacier lobe, are indicative of the oscillating nature of the glacier margin, as it retreated after the last Weichselian ice-transgression (the so called Bælthav Advance, Houmark-Nielsen, 1987).

\section{Pillemark landfill and the water supply in the Pillemark area}

The Pillemark landfill is located at an old peat and gravel pit, where $300,000 \mathrm{~m}^{3}$ of waste were deposited between 1950 and 1988. The waste was disposed over a total area of $28500 \mathrm{~m}^{2}$ with a variable thickness. The waste is $15 \mathrm{~m}$ above ground surface in the northern part of the landfill, while the thickness of the waste layer is $3 \mathrm{~m}$ above ground surface in the in the most southern part of the landfill. The deposited waste includes household waste, construction materials, and, in small amounts, pesticides and paint residuals (Hansen, 2012). High concentrations of inorganic compounds, hydrocarbons, and pesticides have been found in the 
shallow aquifer in contact with the landfill. The shallow aquifer is locally present near the landfill in the top c. 5 $\mathrm{m}$ below ground surface in glaciolacustrine deposits. However, the spatial distribution of the glaciolacustrine sand and, thus, the extension of the shallow aquifer is not known outside the landfill area; this will be further investigated in this study. The equipotential lines of the shallow aquifer are shown in Figure 2. The gradient

5 indicates that groundwater flows locally toward the remediation well. Outside the area of influence of the remediation well, in the southern part of the landfill, groundwater flows north-east to south-west. Slug tests

7 performed at two wells in the glaciolacustrine sandy deposits near the landfill showed an average hydraulic conductivity of $3.010^{-5} \mathrm{~m} / \mathrm{s}$.

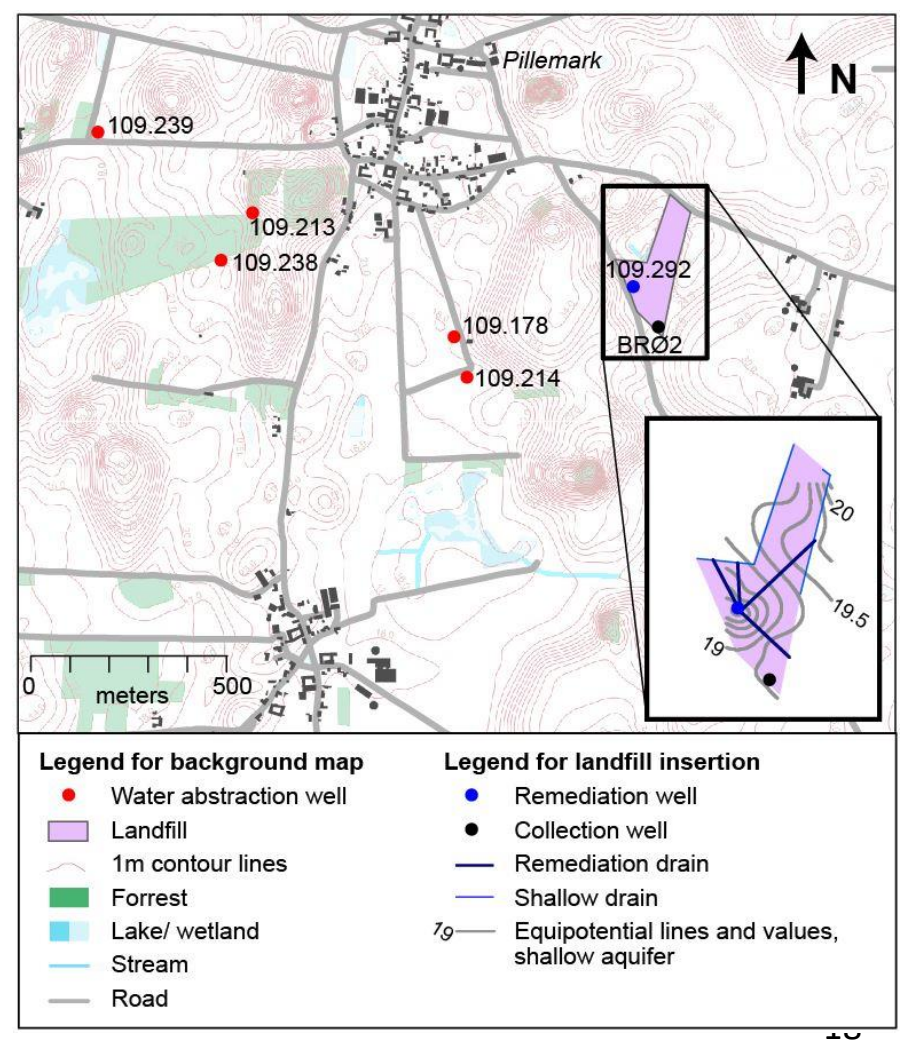

Fig. 2: Map of the Pillemark area showing the water abstraction wells, topography, streams and wetland. The insert shows the isopotential map of the upper aquifer together with the drainage system at the landfill.

Several remedial actions were implemented in order to limit the spreading of the leachate. The landfill has been covered by a thin layer of clayey soils after end of landfilling in order to reduce infiltration and leachate generation. A system of two shallow drains located at the eastern and western edges of the landfill collect the recharge from the surrounding areas to the collection well "Brø2" (Fig. 2). Water is further channelled through 
1 ditches to three wetland areas, before discharging to a creek. A system of four drains, located below the waste deposit, collects the leachate generated at the landfill at well 109.292, where the contaminated water is pumped to a local wastewater treatment plant. The average daily pump rate is $1 \mathrm{~m}^{3} /$ day.

A deep aquifer, used for drinking water abstraction, is located between c. 20 to $35 \mathrm{~m}$ below ground surface in Tebbestrup meltwater sandy deposits. An average hydraulic conductivity of $3.510^{-4} \mathrm{~m} / \mathrm{s}$ was measured at

6 five wells located in the deep aquifer near the landfill area. The closest water abstraction wells are located 300 $m$ south west of the landfill (Fig. 2). The waterworks has a total average pumping rate of $532 \mathrm{~m}^{3} /$ day distributed over 5 water abstraction wells and provides drinking water to the southern part of the island of Samsø. According to the boreholes, the deep aquifer is situated below a thick clay till unit that separates the shallow 10 aquifer that are contaminated by the landfill and the deep aquifer used for groundwater extraction. A key objective of this study is to investigate this clay till unit. Thus, the study will investigate whether this clay till unit

12 1) is fractured 2) if the clay till continues throughout the area and 3) if it is sufficiently thick to protect the deep aquifer from contamination within the coming years.

\section{Geological and geophysical data}

Existing and new geological and geophysical data have been acquired and analysed in the field area 18 (location shown in Fig. 3). The input data for the geological model include; new and existing boreholes, new geophysical borehole logging, new spear-auger measurements, new electromagnetic induction (EMI) measurements, new geoelectrical and time-domain induced polarization (DC/IP) profiling and new and existing transient electromagnetic (TEM) data. 


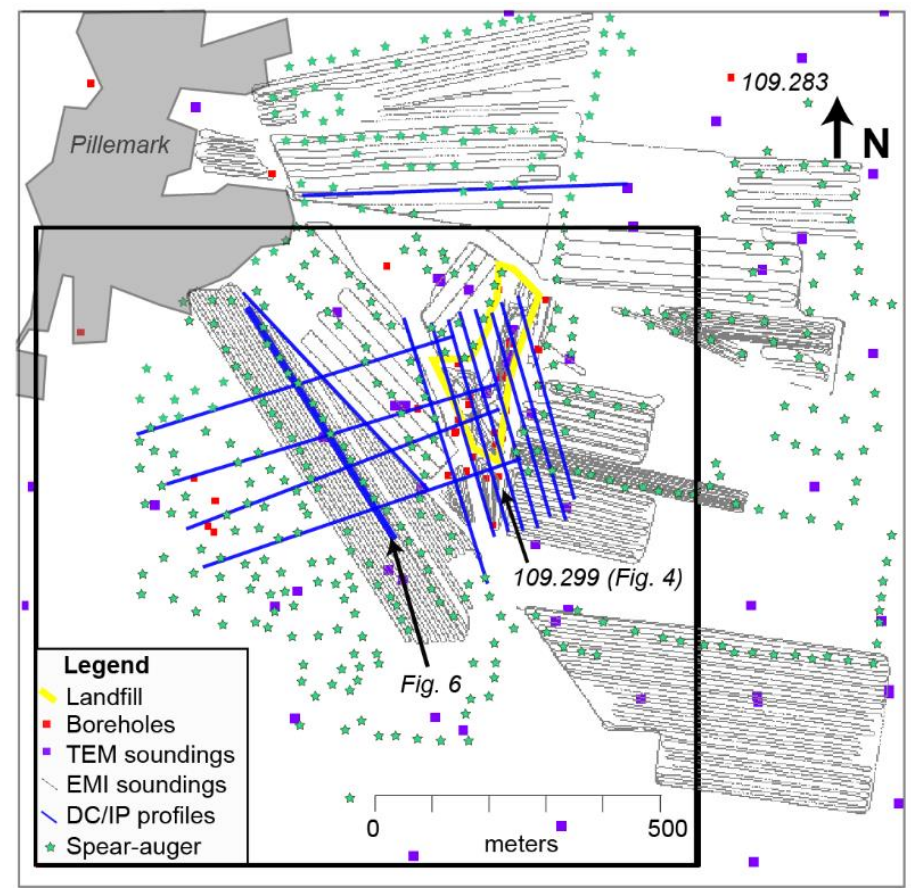

Fig. 3: Location of data in the field area. The model area is marked with a black square. The research borehole 109.299 (Fig. 4) and the stratigraphical borehole 109.283 are marked. Location of the DC/IP profile in Figure 6 is marked as a thick line. The outline of Pillemark landfill site is marked with a yellow line.

\subsection{Boreholes}

\subsubsection{Boreholes from the national Danish borehole database}

Information from around 30 boreholes in the national Danish borehole database (Jupiter) (Fig. 3) is available in the study area (Møller et al., 2009). The majority of these were drilled on, or nearby the former landfill site for monitoring soil and groundwater contamination. Most of the boreholes are shallow and many have relatively poor, or even lack, lithological descriptions. No matter the purpose of drillings, practitioners or public authorities should always ensure detailed borehole reports that includes geological information.

A few deep boreholes penetrate the entire Weichselian glacial deposits and reach the Eemian marine sediments from the last interglacial period. Hereof, a single borehole (109.283 on Fig. 3) penetrates the entire section down to the Prequaternary Eocene marine sediments. This borehole has been thoroughly described lithologically and biostratigraphically and can therefore be used for stratigraphical correlation. 


\subsubsection{Research borehole}

3

4

6

In order to further investigate the geological framework and provide reliable correlation to the geophysical data, a research borehole (109.299 on Fig. 3) was drilled using an augering method close to the landfill site.

The lithological log is shown together with the matrix strength measured with a hand penetrometer in Figure 4.

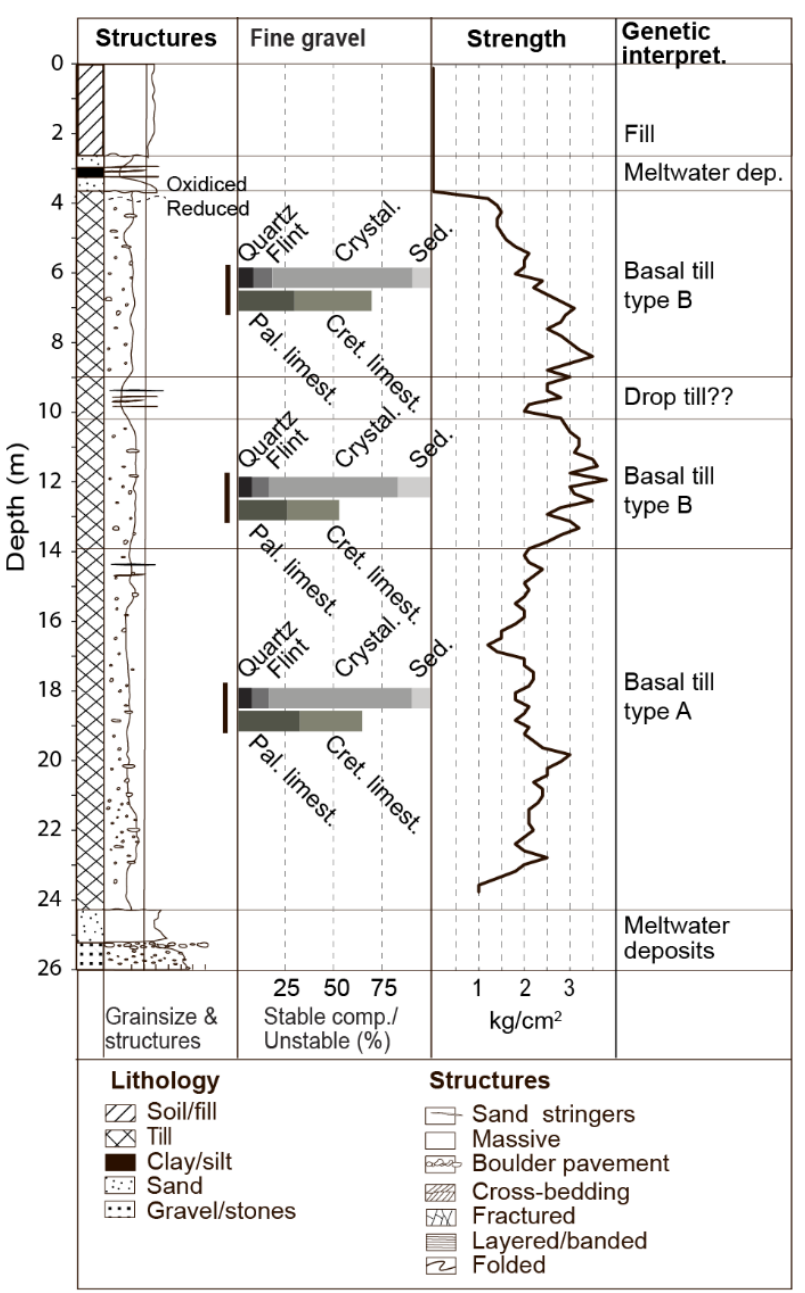

8 Fig. 4: Geotechnical and geological results (lithology, structures, fine gravel analyses and genetic interpretation) in the research borehole 109.299. Location of the borehole is marked in Fig. 3.

The lithological section consists of (1) $2.7 \mathrm{~m}$ of fill material underlain by (2) $0.9 \mathrm{~m}$ meltwater sand and clay, (3) a $20 \mathrm{~m}$ thick sequence of clayey diamict deposits and (4) coarse meltwater sand/gravel from $24.3 \mathrm{~m}$ depth to the bottom of the borehole $26 \mathrm{~m}$ below ground surface, where the deep aquifer is located. The diamict 
sequence (3) is generally massive, reduced and $\mathrm{CaCO}_{3}$ rich. The matrix strength was measured using a hand penetrometer and showed that the diamict is low-to medium consolidated, strongly silty/sandy and weakly

3 gravelly with very little pebbles (Fig. 4). Two sections in the diamict around the depths $9-10 \mathrm{~m}$ and $14-15 \mathrm{~m}$

4 appear weakly consolidated, pebble poor and with thin sand beds. The matrix of the diamict was generally dry

5 until 2 meters above the sandy aquifer, where the diamict became moist to wet. Based on their general 6 appearance, the diamict sediment are classified as basal tills type A (poorly consolidated) and B (consolidated)

7 according to (Klint et al., 2001). However, the presence of laminated homogenous till suggests an aqueous depositional environment and these sections are classified as drop tills.

The question remained whether the till-section consisted of one, two or three superimposed till units. In 10 order to characterize the tills, three representative soil samples were collected for fine gravel analyses using 11 the Dutch method (Ehlers, 1979) of the grain size interval $2.8-4.75 \mathrm{~mm}$. The results are shown in Fig. 4. The 12 fine gravel contents in all three samples showed a high degree of similarity, which indicate that the entire till unit consists of clay till deposited by a glacier originating from the same source area.

\subsection{Near-surface mapping}

The near-surface mapping covers the uppermost 1-2 meters and was developed by combining the results

16 of a traditional spear-auger mapping campaign and the results of an electromagnetic induction (EMI) survey 17 (Fig. 5). 


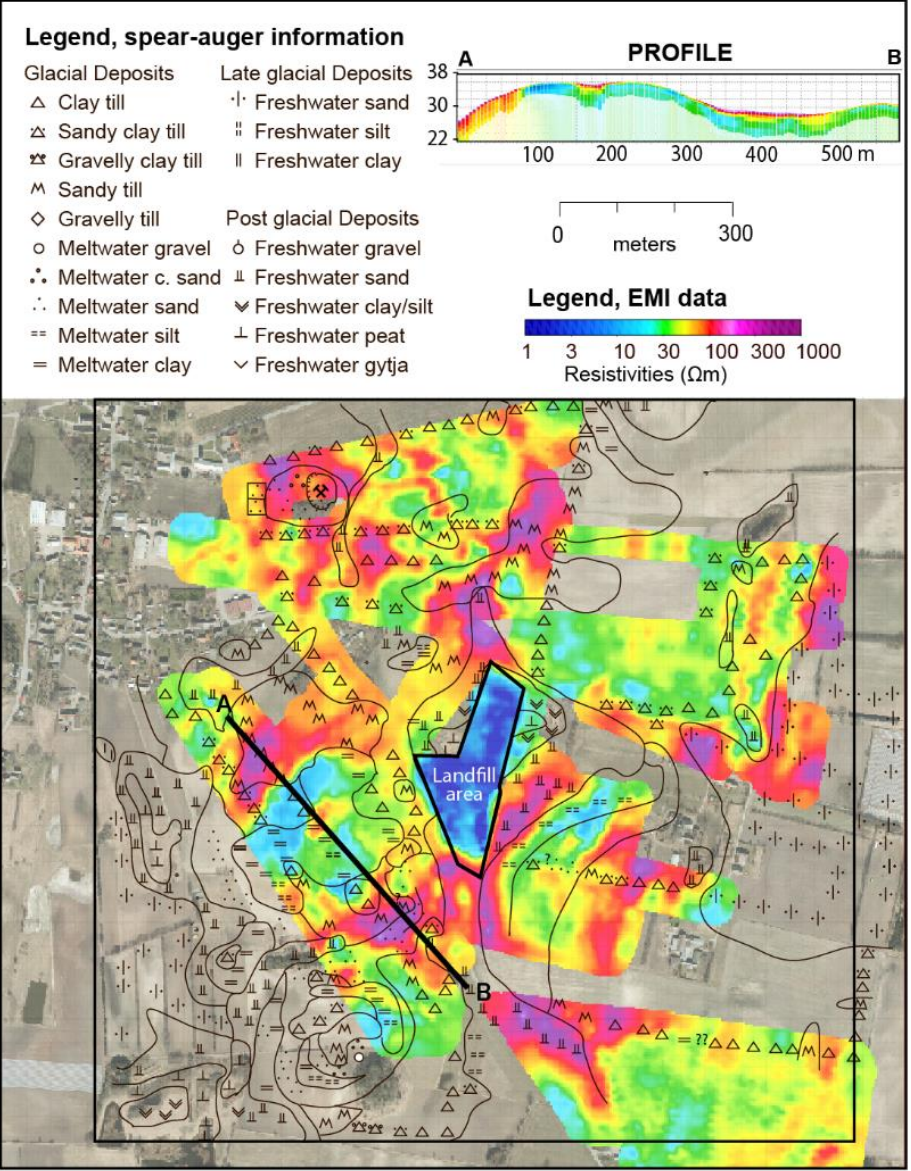

2 Fig. 5: Results of the near-surface mapping in the field area. Inverted EMI resistivity data from 1 - $2 \mathrm{~m}$ of depth are shown together with the results of the spear-auger mapping campaign. The resulting geological map is shown in Fig. 7. The contours illustrate the interpreted units based on a co-interpretation of spear-auger and EMI data. Modified from Klint et al. (2017).

\subsubsection{Electromagnetic induction data}

EMI methods are commonly used for soil mapping. With the development of multi-coil sensors, integration with GPS and use of multi-layer inversion algorithms (e.g. Christiansen et al., 2016; Doolittle and Brevik, 2014) they have become a very fast technique for mapping the very shallow part of the ground surface.

The EMI survey consists of about 85 line $\mathrm{km}$ in the study area and covers about half of the geological model area. The EMI survey was carried out using a DUALEM-421S sensor, which transmitted an electromagnetic wave at $9 \mathrm{KHz}$ in a horizontal coil. The total signal was sampled in horizontal and vertical 
receiver coils located in distances of $1 \mathrm{~m}, 2 \mathrm{~m}$, and $4 \mathrm{~m}$, respectively. The sensor measured 10 times per second and was towed by a motorized vehicle.

The raw EMI data were averaged using a running mean filter of $2 \mathrm{~m}$ and outliers were manually culled. The processed data were inverted using a 1D frequency domain algorithm (Auken et al., 2015). The models were subsequently linked by 3D constraints to obtain a pseudo 3D resistivity model (Viezzoli et al., 2008). The data were inverted using 10 layers that covered the upper $10 \mathrm{~m}$ of the ground. However, the mean depth of investigation was only $6 \mathrm{~m}$ (Christiansen and Auken, 2012). The interval resistivity at $1-2 \mathrm{~m}$ below ground surface was calculated and used together with the spear auger mapping (Fig. 5) to compile the detailed geological map.

\subsubsection{Spear auger mapping}

The spear-auger mapping campaign (Fig. 5) was conducted after the EMI mapping. The data were collected using the traditional methodology for mapping near surface soils in Denmark (Jakobsen et al., 2011). The mapping tool consists of a one-meter-long spear auger with a $15-25 \mathrm{~cm}$ long slit in the side of the spear that captures a small soil sample, when the spear is pushed into the subsurface. The mapping geologist interprets the origin of the sample and place markings on a field map according to the terminology described by Jakobsen et al. (2011). Traditionally, the transitions between different soil types are mapped by the geologist in the field. The symbols are subsequently transferred to a master map sheet, where the various soil types are marked with color-codes on the final geological map. In this survey, the spear-auger measurements were marked on the map (Fig. 5), while the final geological map was developed by co-interpreting the spear-auger measurements and the EMI-data (Klint et al., 2017).

\subsection{DCIP data}

Geoelectrical or DC-resistivity methods have been used for geological and hydrogeological mapping for decades. Recently, induced polarization (IP) methods have been employed for mapping hydrogeological properties and, at landfill sites, waste disposal (Gazoty et al., 2012a; Loke et al., 2013; Revil et al., 2012).

The DCIP survey comprises 15 profiles resulting in about 8 line $\mathrm{km}$ with the highest data density across 
1 (Dahlin and Zhou, 2006) were used with current electrode separations between 40 and $360 \mathrm{~m}$. The raw data were processed according to the processing schemes in Olsson et al. (2016) and inspected for manual cull of outliers not caught by the filters. The processed data were inverted by a procedure (Fiandaca et al., 2013) solving for the Cole-Cole parameters (e.g. Pelton et al., 1978). The depth of investigation (DOI; Christiansen and Auken, 2012) varies along - and between the profiles, but are generally situated below the deep aquifer, corresponding to depths between $40-70 \mathrm{~m}$. The DOI for the resistivity sections is calculated from the sensitivity matrices following Christiansen and Auken (2012), which takes the actual data errors and specific model into account.

The geological interpretation and modelling were mainly based on the electrical resistivity rather than on the chargeability parameters (not shown). The resistivity values of a certain deposit is dependent mainly on the salinity of the porewater and the clay content of the sediment. Thus, in areas without saline groundwater, sands and gravels will typically show high resistivities and clayey deposits show low resistivities (Barfod et al., 2016). Deposits saturated with contaminated porewater will therefore show low resistivities. This is recognized in Fig. 5, where the EMI data show very low resistivities (5-10 ohm-m) in the area at the landfill. In these areas, the geology was mainly interpreted based on the borehole information. However, in these areas, also the chargeability parameters gave valuable information, since they helped discriminating whether the low resistivities originated from clayey deposits or from coarse-grained deposits saturated with contaminated porewater (Maurya et al., 2018).

An example of one of the resistivity sections is displayed in Fig. 6 . The resolution of the DCIP data is better in the top 20 m below ground surface compared to the deeper part of the setting. In the deeper part of the setting, the resistivity models are highly influenced by equivalences. Both the high and low resistivity equivalences are too prominent to be resolved, despite the improved resolution of resistivities and inverted models using the combined inversion of DC and IP data (Madsen et al., 2017). The severe high and low equivalence implied that the top of the high-resistive layer at about 5-10 m.a.s.l. is located 5-10 m above the top of the meltwater sand as depicted by the boreholes (about 0 m.a.s.I.). The level differences between the top of the sand in the boreholes and the corresponding high-resistive layers in the geophysical data is especially pronounced in the hilly areas, where the top of the high-resistive layer tends to follow the terrain 
1 (e.g. Fig. 6). This is inferred to be a consequence of the lateral constrains used in the DCIP inversion, where 2 the geophysical models are highly influenced by equivalences.

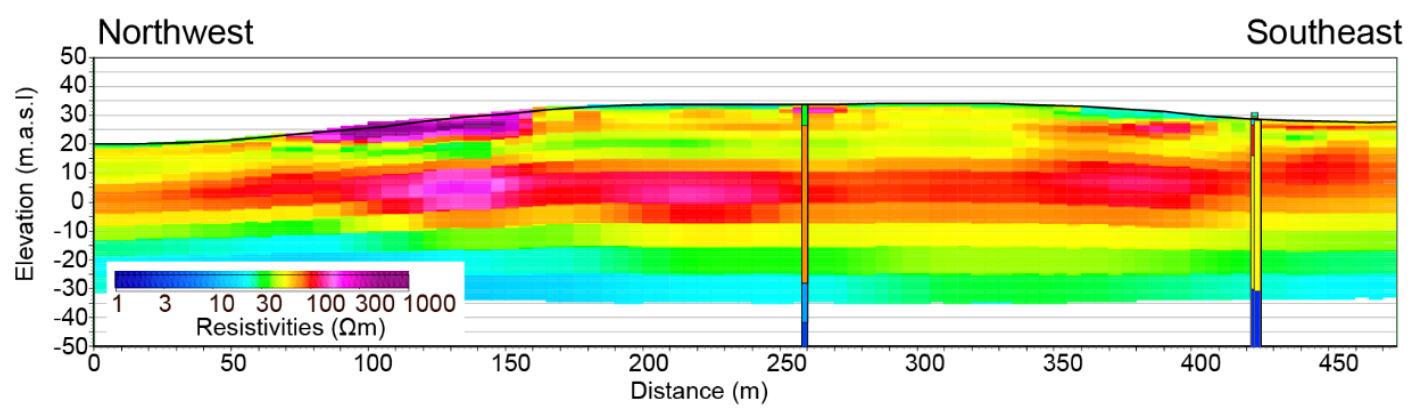

Fig. 6: Distribution of electrical resistivity along one of the DCIP profiles (for location see fig. 3). 1D TEM models located within a buffer of $100 \mathrm{~m}$ from the profile are shown (profile distance $=260 \mathrm{~m}$ and $420 \mathrm{~m}$ ). The DOI is situated within the bottom layer below -30 m.a.s.I. and is not displayed on the section. No vertical exaggeration.

\subsection{TEM data}

The transient electromagnetic method (TEM) is a commonly used tool for hydrogeological mapping (Fitterman and Stewart, 1986; Sørensen et al., 2005). The majority of the TEM data available at the site were acquired during a groundwater mapping campaign in 2002 and were downloaded from the Danish national geophysical database (GERDA) for this study (Møller et al., 2009). These TEM data were supplemented with a number of new TEM soundings. Both surveys were conducted using a $40 \mathrm{~m}$ by $40 \mathrm{~m}$ transmitter loop attaining a depth of investigation about $100-150 \mathrm{~m}$ depending on the resistivity structures in the ground. The processed data were inverted following a 1D inversion approach solving for layer resistivities and thicknesses (Auken et al., 2015). The TEM soundings were inverted using a few-layer approach, in which only significant resistivity changes are resolved.

The TEM data could not resolve the geological stratification in the upper part of the ground surface, as shown in Fig. 6, but were employed to inform about the depth to the good conductor.

\section{Geological interpretations}

\subsection{Geological map}

A geological map (Fig. 7) was constructed by a combined interpretation of the spear-auger mapping with the EMI resistivity in the depth interval $1-2 \mathrm{~m}$ (Fig. 5) (Klint et al., 2017). This depth interval is equivalent to 
1 the depth of the data collected using the spear-auger method $(\sim 1 \mathrm{~m})$. EMI data from the uppermost meter was excluded because the resistivity can be greatly influenced by the humidity of the soil. Due to the time-effective

3 EMI data acquisition, these data were more densely spaced than the spear-auger measurements (Fig. 5).

4 Thus, in areas without spear-auger information, the EMI resistivity data were utilised to outline the boundaries 5 between deposits with different conductive properties, such as clay and sand (e.g. Barfod et al., 2016).

The depositional environments were interpreted by combining the EMI data with the results of the spearauger mapping and the geomorphological analyses (Fig. 7). Thus, whereas the EMI data give valuable spatial 8 information to distinguish between clayey and non-clayey material, the method does not provide information on the depositional environments. By combining the EMI mapping with the spear-auger measurements, it is 10 possible to utilize the resistivity values in the construction of the geological map. When doing this, the spatial information from the resistivity data is used to determine the boundaries between the individual geological 12 units in areas without spear-auger information. In these areas, the changes in resistivity values have been used to locate the boundaries between deposits based on a local analysis of the lithology-resistivity relation 14 and extrapolation from the spear-auger mapping points (Bockhorn et al., 2015). With this approach, it is possible to obtain significantly more precise boundaries between the units than if using the more sparsely distributed spear-auger data alone.

The geological map in Figure 7 shows that postglacial and late glacial freshwater deposits dominate in the low-lying areas. Clay till deposits are most common on plains, while the hills are mainly constituted by glacial 19 meltwater clay and sand, partly covered with sandy and clayey tills. On the geomorphological map (Fig. 2b) these hills are classified as overridden kames. The Pillemark landfill site is located in a low-lying area 21 surrounded by small hills west and east of the site. This depression is probably a result of buried ice melting, leaving a kettle hole that developed into a lake and later on the peat bog that was excavated prior to the use as a landfill site. 


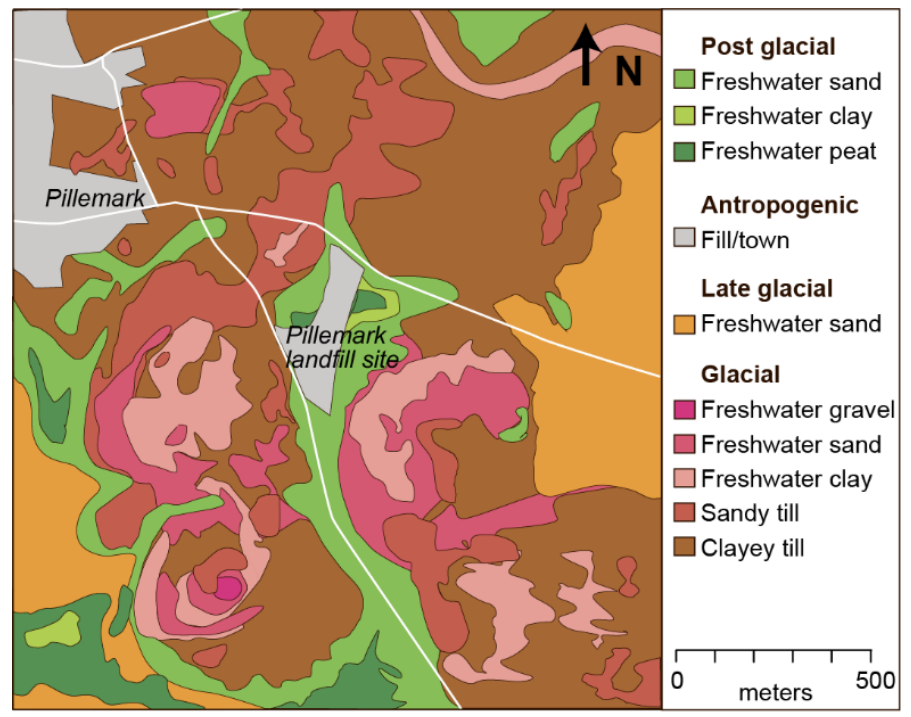

Fig. 7: Geological map based on the results of the surface mapping campaign (Fig. 5). Modified from Klint et al. (2017).

\subsection{Geological history of the study area}

The new geological and geomorphological maps have been used together with borehole information and the geophysical data to derive a conceptual geological understanding of the area. The stratigraphical information from the boreholes was vital for setting up the geological history of the area and thus, making a geological model with this degree of detail. This includes the biostratigraphical information from the already existing borehole 109.283 (Fig. 3) and the detailed lithological information and fine-gravel analyses from the new research borehole (Fig. 4). The conceptual sketch illustrating the inferred development stages of the study area is shown in Fig. 8.

During the Eocene, very fine-grained marine clay was deposited in a deep ocean. Oligocene and Miocene deposits are absent in the area, and the Saalian tills, therefore directly overly the Eocene deposits. The top of the Eocene clay appears at different levels and sometimes above glacial deposits, indicating widespread glaciotectonic deformation by the Saalian ice-sheets. The Saalian tills are overlaid by marine clays deposited in the Eemian interglacial period. The Eemian deposits are situated 20 to $40 \mathrm{~m}$ below present sea level, and since the Eemian sea level was above the present, it indicates that Samsø was situated in a marine environment in this period. 
The oldest Weichselian deposits are situated above the Eemian deposits and below the main aquifer.

2 These were probably deposited during the Old Baltic Ice Advance corresponding to the Ristinge Till Fm.

3 (Houmark-Nielsen 1987) about 50 - 55,000 BP (Houmark-Nielsen, 2007). In relation to the main North-Eastern

4 (NE)-ice advance, meltwater sand and gravel was deposited in front of the glacier on a proglacial meltwater

5 plain (Fig. 8a). These deposits can probably be correlated to the massive occurrences of meltwater deposits

6 in central Denmark assigned to the Tebbestrup and the Hedeland Formations (Houmark-Nielsen, 1987). At

7 Sams $ø$, these deposits are correlated to the Tebbestrup Fm. and constitute the main aquifer in the study area.

8 Given the relative position, the till unit above should accordingly be assigned to the Mid Danish Till Fm., which

9 was deposited during the main glacial advance by glaciers advancing from NE (23-20,000 B.P.) (Fig. 8b). This

10 till sequence was mainly deposited sub-glacially, while the lacustrine sequences were deposited in an ice

11 dammed lake during a glacial retreat and re-advance. However, another explanation for these glaciolacustrine

12 deposits might be deposition during an episode of basal ice bed separation, which can occur during episodes

13 of high water saturation of the glacier (Piotrowski and Tulaczyk, 1999). The fine gravel analyses of the till

14 showed that the till contained considerably more limestone than the Baltic tills described by Houmark-Nielsen

15 (1987). This supports the theory that the till is deposited by a glacier advancing from $\mathrm{N}$ or NE, since the source 

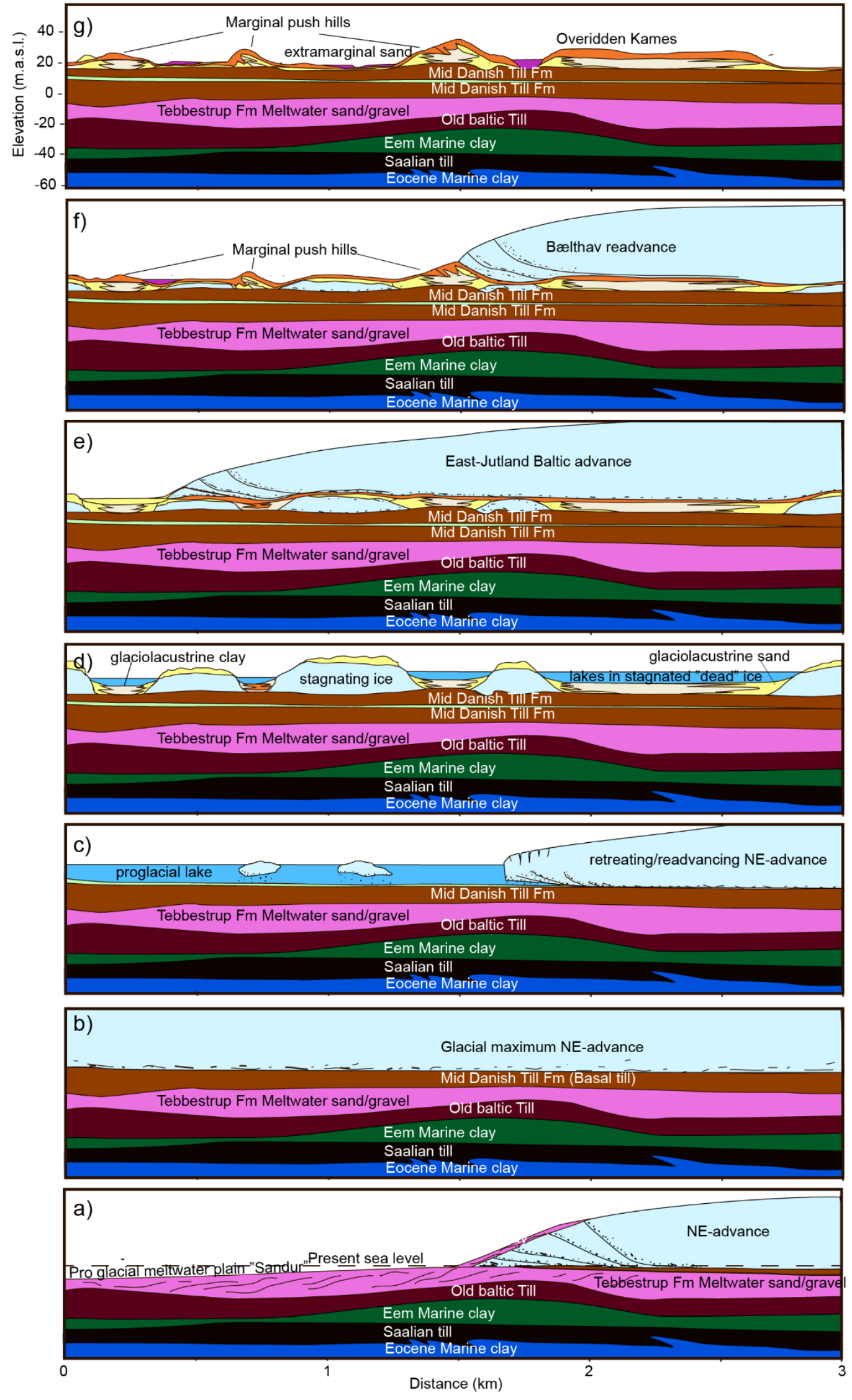
Fig. 8: Conceptual sketch illustrating the inferred development stages of the study area (to be read from the bottom to the top going from the oldest to the youngest stage). $6 x$ vertical exaggeration.

area for the limestone in the pre-Quaternary basement is situated just NNE of Samsø. The fine-gravel analyses therefore support the correlation of the till to the Mid Danish till Fm. This conflicts with the findings of HoumarkNielsen (1987), who argued that the Mid Danish till Fm. was only sparsely found on Samsø and furthermore correlated most of the lowest "Baltic tills" along the coast of Southern Samsø to the Saalian glaciation. Nevertheless, due to the relative position, and the fine gravel analyses, the Mid Danish till Fm. is considered the most likely age of this thick till formation.

The identification of glaciolacustrine clays in a number of boreholes suggest that a proglacial lake was established during the retreat of the NE ice advance (Fig. 8c). During the regression of the NE-ice, stagnating ice was left behind and lakes were formed between the buried dead-ice. Glaciolacustrine clays were deposited in the middle of these lakes, while glaciolacustrine sand or gravel were deposited closer to the shore, where the energy level was higher (Fig. 8d). The area was later transgressed by the East-Jutland Baltic advance (Fig. 8e) and the Bælthav advance (Fig. 8f), resulting in the deposition of tills on top of the still buried ice, and the formation of marginal push hills (Fig. 8f). As the glaciolacustrine deposits were transgressed, the overridden kame hills were generally covered with Bælthav tills. This is especially pronounced in the eastern side of the kame hills, corresponding to the direction of the ice-flow. Finally, the buried ice melted and large areas subsided and formed the hummocky terrain that covers large parts of Samsø today.

A conceptual sketch of the present situation is shown in Figure $8 \mathrm{~g}$. The terrain surface is located around $20 \mathrm{~m}$ to $40 \mathrm{~m}$ above the present sea level and the terrain is characterized by a glacial landscape consisting of marginal push hills and overridden kames. Between the hills, late- and post-glacial deposits as extramarginal sand and freshwater peat dominate.

\section{Geological modelling strategy}

A geological model was constructed in the modelling software Geoscene3D (I-GIS, 2014) for the $1.25 \mathrm{~km}^{2}$ model area marked in Figs. 1b and 3. This area was selected in order to investigate the vulnerability of the 
1 (the deep) main groundwater aquifer beneath the Pillemark landfill site and the hydraulic connectivity between the landfill site and the water supply wells.

The model covers the layers from Top Eocene to the terrain surface and consists of a combined layerbased and voxel model: The layers below the Tebbestrup Fm. were modelled using a layer-based approach, whereas manual voxel modelling was used above (Fig. 9). The voxel model has a discretisation of $5 \mathrm{~m} \times 5 \mathrm{~m}$ laterally and $1 \mathrm{~m}$ vertically. Voxel modelling was utilized in order to enable the resolution of the heterogeneous small-scale structures that are impossible to resolve using traditional layer-modelling (Høyer et al., 2015).

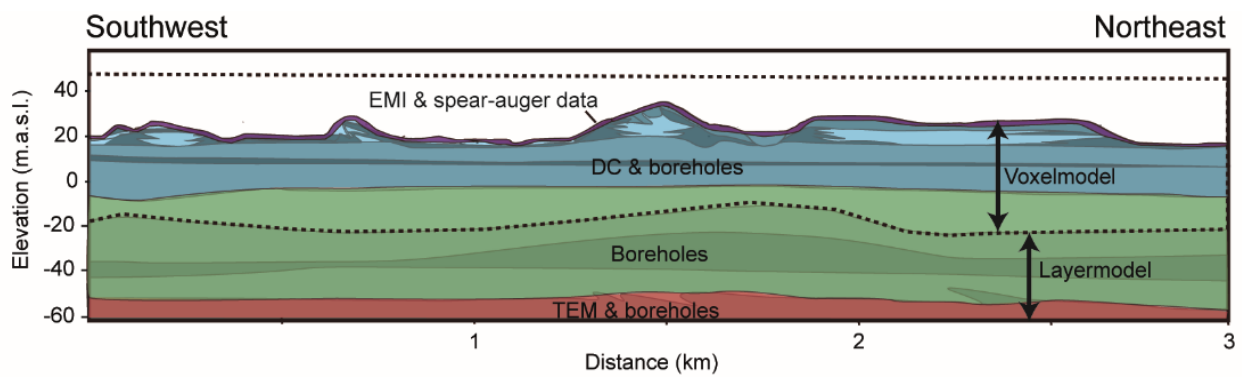

Fig. 9: Modelling strategy illustrated on top of the conceptual geological sketch of the modelling area (Fig. 8g). The colours indicate the prominent use of different data types at different depths in the model. The dashed polygon mark the part of the model that is modelled using voxel modelling.

Due to the different resolution of the methods, emphasis were put on different data types at various depths as illustrated in Figure 9. Thus, the upper 1-2 meters of the model was based on the detailed geological map derived from the co-interpretation of the EMI and spear-auger data (Fig. 7). The layers below, down to c. 20 $\mathrm{m}$ of depth, were mapped and modelled with valuable support of the DC-resistivity data. These data were especially useful in the modelling of the infill of the kame hills (Fig. 9). Below, the DC data showed high and low equivalences and a 5-10 m misfit between the position of the top of the high resistive layer in the DC data and the sand layer in the boreholes. For modelling purposes, information from boreholes were considered more accurate than the DC resistivity data, because of the good correspondence between borehole data and the expected depositional environment. The layers from the top of the sand layer (the Tebbestrup Fm.) to the top Eocene was therefore modelled based on borehole information alone (Fig. 9). The TEM data supported the interpretation of the top Eocene boundary, since the Eocene deposits are characterized by very low resistivity, recognised with the TEM method. 


\subsection{Layer modelling}

Layer modelling was used to model the top of four geological formations: Top Eocene, Top Saalian till, Top Eemian clay and Top Old Baltic till (see Figs. $8 \mathrm{~g}$ and 9). The layers were constructed by making interpretation points throughout the area and interpolating these using kriging (using spherical variograms) to generate the corresponding stratigraphical surfaces. The initial interpretation points were placed at locations with reliable data. When necessary, free interpretation points were added between data to control the surfaces. Each interpretation point was attached a qualitative uncertainty estimate ranging from 1 (low uncertainty) to 4 (free interpretation point).

The primary data basis for the interpretations was the borehole and TEM data (Fig. 9). Only the boreholes can provide stratigraphic information and unfortunately, few boreholes penetrate to these depths. The stratigraphy was therefore setup based on the conceptual model (Fig. 7) as well as the results of the biostratigraphical borehole, located just outside the model area (109.283 in Fig. 3). The Eemian marine clays are penetrated by three boreholes in the area and constitute an exceptional marker horizon. Furthermore, the main aquifer is penetrated by multiple boreholes, which enable the use of this formation as an important stratigraphic marker horizon. The TEM data were mainly utilized to define the top of the good conductor, corresponding to the Eocene clay. However, since all the layers below the Tebbestrup Fm. are characterized by low to very low resistivity, a close co-interpretation of the TEM data and the stratigraphic information from the boreholes was necessary when using the TEM information in the modelling.

\subsection{Voxel modelling}

The detailed voxel model was created for the units above the Old Baltic till corresponding to the upper 40 to $60 \mathrm{~m}$ of the model. The model was defined with cell sizes of $5 \mathrm{~m}$ horizontally and $1 \mathrm{~m}$ vertically, resulting in a model with 4.4 million voxels. The small cell size was chosen in order to be able to incorporate the details encountered in the data. The modelling is performed using the voxel modelling tools described in Jørgensen et al. (2013).

The lowermost layers in the voxel model (the Tebbestrup Fm. and the Mid Danish till Fm.) were initially modelled using a layer-based approach and subsequently filled with voxels. Many of the boreholes penetrate the Tebbestrup Fm. According to all these boreholes, the top of the formation is located close to the present 
sea level ( 0 m.a.s.I.). The apparently flat top of this layer is in agreement with the depositional environment. Hence, since the Tebbestrup sand and gravel were deposited on a sandur plain, the top is expected to show 3 a very smooth and steady (near-horizontal) dip (Fig. 7a), if not subjected to subsequent erosion. The top of the Tebbestrup Fm. was therefore modelled as a relatively flat surface located around the present sea level.

5 Above the Tebbestrup Fm., clay till was recognized in the boreholes. Fine-gravel analyses from the new research borehole (109.299, Fig. 4) show that these deposits probably belong to the same formation. Based on the relative position of this till, it was assigned to the Mid Danish till Fm. The glaciolacustrine deposit defined

8 in the middle of the Mid Danish till Fm. (Fig. 8c) was not modelled, since this deposit was only described in 9 very few boreholes and could not be interpolated accurately. The Mid Danish till Fm. was consequently modelled as one thick ( $20 \mathrm{~m})$ unit with relatively uniform deposits.

The setting above the Mid Danish till Fm. near-surface part of the voxel model was entirely modelled using manual voxel modelling tools. The conceptual understanding of the area (Fig. 8g) was crucial during this modelling. Within the kame-hills, the deposits were interpreted and modelled as glaciolacustrine sand or clay, based on the borehole and DCIP data, as well as on the landscape and geomorphological analyses. Coarsegrained deposits are therefore most common in the rim of the kame hills, while fine-grained glaciolacustrine clays appear in the middle. Where DC-resistivity data was available, these were utilized to delineate the boundary between sandy and clayey deposits. This is illustrated in Fig. 10, where a horizontal slice through the geological model is shown together with DC-resistivity data from the same elevation. On the kame hills, glaciolacustrine sand and clay were interpreted in areas with high and low resistivities, respectively. The DCresistivity data supported the conceptual geological model by showing high-resistive deposits in the rim of the kame hill (Fig. 10). 


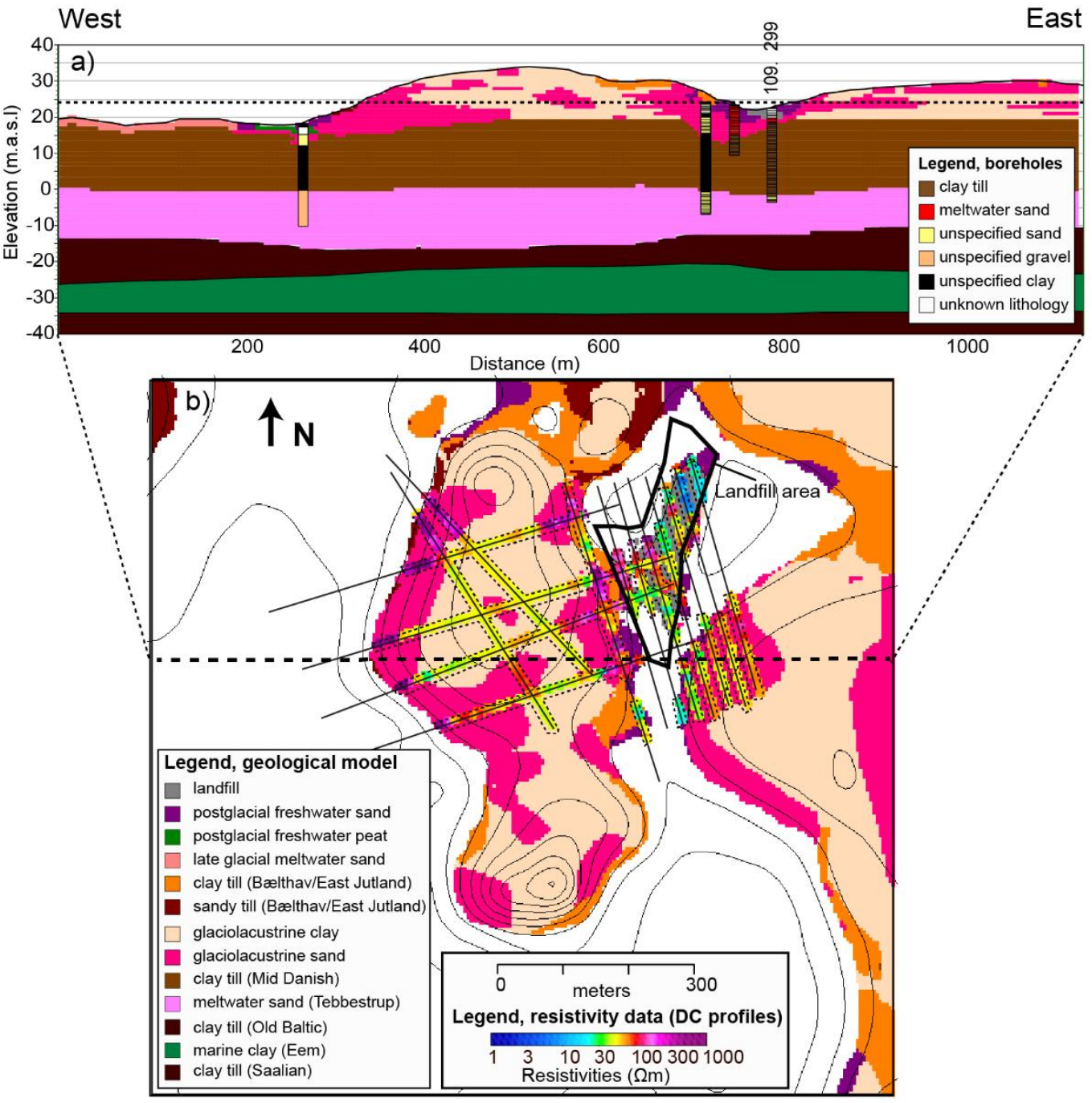

2 Fig. 10: Horizontal and vertical slices through the geological model results, a) E-W profile shown together with boreholes within 80 m of the profile. The research borehole 109.299 (Fig. 4) is marked. Vertical exaggeration

$4=4 x$. The dashed line marks the elevation $24 m$ corresponding to the elevation of (b), b) horizontal slice at elevation $24 \mathrm{~m}$ shown together with a 3D grid of the DC-resistivity data (within dashed areas). $2.5 \mathrm{~m}$ contour lines are shown in black. The dashed line shows the location of the profile in (a)

The uppermost one or two meters of the voxel model were ascribed lithologies corresponding to the ones

8 defined in the geological map (Fig. 7). This was chosen as it matched the depths for the surface mapping.

9 Dependent on the type of deposit, some were modelled to greater depths (e.g. $5 \mathrm{~m}$ ) while others, like 10 freshwater peat, were modelled only in the shallow (e.g. 1-2 m) part. 


\section{Geological model results}

Three of the modelled layers (the Saalian till, the Eemian clay and the Old Baltic till) are shown together with the voxel model results in the vertical slice in Fig. 10a. In this figure, it is seen how the lower part of the

4 setting, the Saalian till to the Mid Danish till Fm., are modelled as homogenous layers that show smooth layer 5 boundaries with only little topographic variations. The most steady layer boundary is the top of the Tebbestrup

6 Fm. that is located around 0 m.a.s.l. (Fig. 10a). Also, when observing the vertical slices through the 3D model, 7 it is apparent that the Tebbestrup Fm. shows an overall flat upper layer boundary (Fig. 11a).

The upper part of the geological setting (above the Mid Danish till Fm.) is more heterogeneous (Figs. 10 9 and 11). Inside the kame hills (profile distance $300-1100 \mathrm{~m}$ in Fig. 10a and Fig. 10b), glaciolacustrine clay, sand and gravel dominate. The glaciolacustrine clay dominates in the middle of the kame hills, while the 11 coarse-grained deposits are common in the rim of the hills. Coarse-grained deposits are also occasionally present within the centre of the kame hills (e.g. profile distance 550 m, Fig. 10a).

In the very near-surface, the deposits are characterized by tills from the Bælthav/East Jutland advance, 14 late glacial meltwater deposits and postglacial freshwater sand or peat (Fig. 11b). As observed in Fig. 10b, the glacial deposits are most commonly observed on the central and eastern side of the kame hills. Some of the

16 kame hills show glaciolacustrine deposits all the way to the surface. In the topographic lows, postglacial freshwater sand and peat dominate. In the western part of the area, late glacial meltwater sand appears at the surface. 


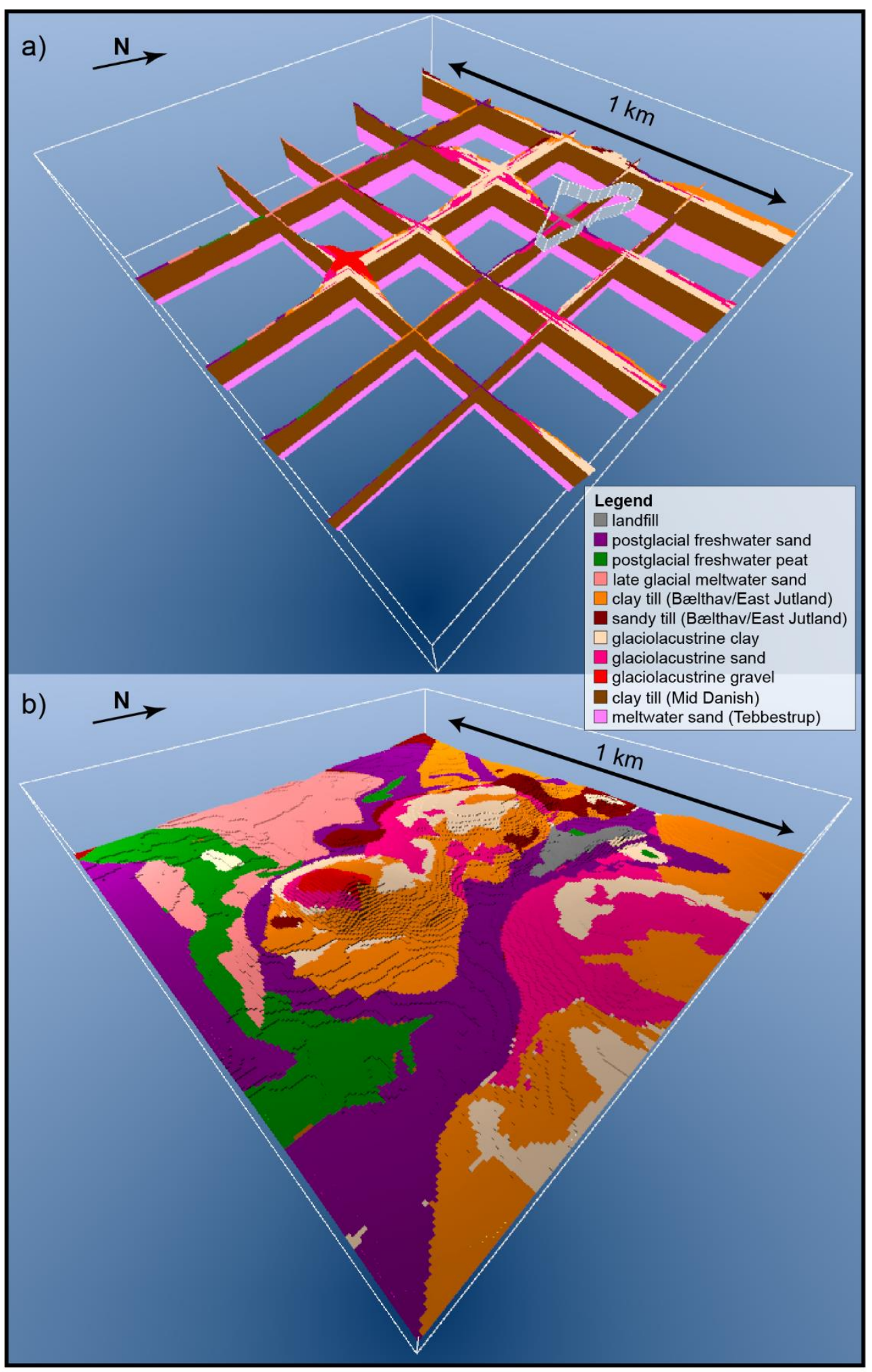

2 Fig. 11: View of the 3D voxel model results (the deposits above the Old Baltic till Fm.) a) N-S and E-W slices 3 through the $3 D$ grid. A polygon marks the landfill area, b) $3 D$ model results seen from above. Vertical exaggeration $=3 x$ 
The landfill can potentially pose a risk for surrounding waterbodies, which are a small creek downgradient and the underlying groundwater aquifer used for abstraction for the water abstraction wells (Fig. 2). Other kinds of risk include human exposure to contaminated waste/soil or vapours. Since the area is used for grassland and there is no nearby housing, these risks are expected to be small and will not be further discussed.

The drainage system around the landfill is connected to a ditch, which leads into the creek. This can potentially cause contamination of the creek and downgradient wetland areas. The upper hummocky landforms are dominated by dead-ice processes (Fig. 8g). These landforms are characterised by a generally high degree of heterogeneity as they have been subjected to both backwasting and downwasting processes during melting of buried dead-ice, but also glaciotectonic deformation has deformed the sediments during transgression of the young Baltic ice-advances (Fig. 8g). The lacustrine sand layer becomes thinner and disappears around 50 m downgradient from the landfill (Fig. 12a). The isopotential map indicates a southerly groundwater flow in the outskirts of the landfill to the south, which is not affected by the remediation well (Fig. 2). Leachate migration in this layer can be further spread to wetlands and the creek.
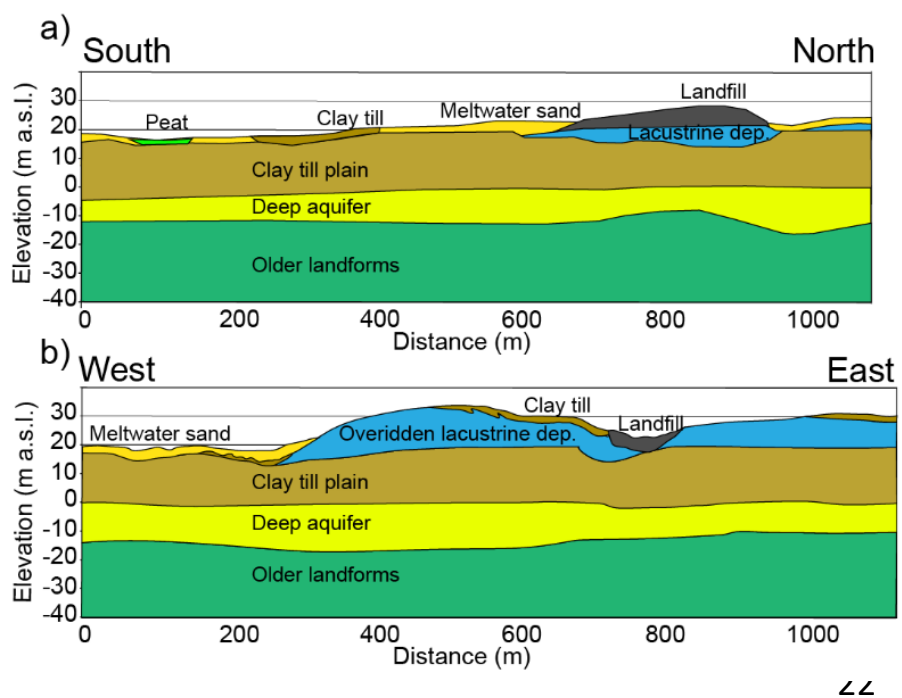

Fig. 12: Conceptual sketches of the geological setting in the Pillemark landfill area, a) South-North profile, b) West-east profile. 
The clay till plain in the area is crucial for the protection of the deeper groundwater aquifer. The till plain is considered one unit with an average thickness of 15-20 meters, based on the fine gravel analyses (Fig. 4)). This unit is considered relatively homogenous having a regional lateral distribution throughout the model area

(Fig. 12). Based on the strength properties, the lower part of the till is classified as basal till type A (nonfractured) and together with the total thickness, the thickness of the reduced clay and the general consolidation, this unit is considered massive and poorly fractured (Fig. 4). Accordingly, it provides a good protection between the landfill and the deeper aquifer below; however, the downward hydraulic gradient observed will cause vertical movement of contamination by advection. Thus, although this preliminary assessment suggests that groundwater sources for the waterworks is well protected, there may be a risk for contamination of the deep aquifer (Fig. 12). Future studies may further develop the preliminary risk assessment presented in this study by assessing the drainage system, the effect of the remedial pumping, the leachate quality, and the actual impact on the downgradient water bodies (stream, deep groundwater aquifer).

\subsection{Methodology}

In this study, a combined use of geophysical and geological data and coherent geological interpretation illustrate that the uncertainty on the risk assessment can be reduced. Furthermore, the significantly increased understanding of the geological setting of the area may imply that the overall risk of contaminating the main aquifer may be lower than previously expected.

Unravelling and updating the geological history of the area have been crucial for the geological interpretation of the geophysical data and thereby also for the reduction of uncertainty of the risk assessment. The new data in the study; the approach of combining an EMI survey and traditional geological surface mapping (Klint et al., 2017), the new research borehole data and the new geomorphological map, have resulted in an updated conceptual geological understanding of the hills in the area to be overridden kame hills deposited in ice-dammed lakes (Fig. 8d-f). The coherent interpretation of the DC resistivity data made it possible to distinguish the glaciolacustrine clay and sand/gravel located in the kame hill cores and rim, respectively. The new data and interpretation have concluded that the upper secondary aquifer consists of late glacial meltwater sand outside the kame hills and glaciolacustrine sand inside the kame hills. It does therefore not form a continuous layer as older interpretations have suggested. The investigation have therefore reduced the uncertainty of the geological part of the baseline study and thereby the uncertainty of the risk assessment. 
In this study we have used a deterministic approach to geological modelling, resulting in one conceptual geological model. As mentioned above, the geological model is associated with uncertainty due to a number of reasons - including factors like; uncertainty in the data, uncertainty related to the translation of geophysical information to geological information and uncertainty related to the conceptual geological understanding. The uncertainties are crucial to consider, especially in studies like these, where the model informs about contamination risk of an important aquifer. In this study, the uncertainties have been evaluated qualitatively during the geological modelling. Another approach that is used more and more frequently, in order to obtain more quantitative measures for the uncertainty, is the use of multiple realisations to illustrate the structural variation based on the given data basis (e.g. Barfod et al., 2018; Feyen and Caers, 2006; He et al., 2013; Huysmans and Dassargues, 2009; Pirot et al., 2015; Refsgaard et al., 2012; Troldborg et al., 2010).

Detailed characterization of the different geological units based on the biostratigraphical information (Borehole 109.283 in Fig. 3) and the detailed lithological information from the new research boreholes (Figs. 3 and 4), were crucial when evaluating the heterogeneity and estimating hydraulic conductivities. Hydraulic conductivities vary significantly within the same type of deposit, depending on factors like; (1) sorting, (2) heterogeneity, (3) compaction, and (4) fractures (e.g. Berkowitz, 2002; Keller et al., 1986). For instance, fractured tills typically show very high hydraulic conductivities contrary to the slow groundwater flow characteristic for massive, solid tills (Berkowitz, 2002). In this study, the till above the primary aquifer, (the Mid Danish till Fm.), was described as relatively homogeneous, primarily massive and without fractures, which is in agreement with the inferred depositional history. Groundwater flow through the till is therefore expected to be slow. Despite the ambiguous DC resistivity models (Fig. 6) a coherent interpretation implying the conceptual geological understanding suggests that the Mid Danish till Fm. is modelled as a continuous and rather thick layer (Figs. 10a and 11a), which significant will reduce the risk of contaminating the primary aquifer compared to a thinner and discontinuous till layer, which was a possible interpretation before this study. 


\section{Conclusion}

In this study, geophysical, geomorphological and geological information were combined to provide new insight on the geological history of Samsø, central Denmark. The new insight was utilized in high-resolution 3D geological modelling of the area surrounding the former Pillemark landfill. The new geological model provides a framework for risk assessment and groundwater protection. All the data and analyses in the study contributed to the interpretation and modelling: (i) The initial regional study of the geomorphology secured a fundamental understanding of the depositional environment in the study area. (ii) The near-surface mapping campaign was conducted using a new approach combining both spear-auger mapping and near-surface electromagnetic induction data. By combining these methods, it was possible to make a high-resolution geological map, which was used to assign the lithology to the uppermost 1-2 meters of the geological model. iii) High-quality information from a new research borehole and an already existing biostratigraphical borehole were used to set up the stratigraphy of the study area and to interpret the geophysical data. The remaining boreholes provided point-information regarding the lithologies, which was especially decisive when modelling the top of the main aquifer in the study area. iv) The geoelectrical profiles were used to provide information about the distribution of clayey (electrically conductive) and sandy/gravelly (electrically resistive) deposits in the near-surface, especially across the kame hills. In the landfill area, where the porewater is saline and the resistivity values therefore are low, IP data and borehole information were co-interpreted to discriminate between clayey and sandy deposits saturated with contaminated porewater. Finally, v) the electromagnetic data provided information about the depth to the good conductor. Due to data uncertainties and equivalences of the geophysical inversions, different methods did not always lead to the same interpretation. This emphasized the importance of considering data strengths and weaknesses as well as the conceptual understanding of the area during the interpretation. The geological modelling was performed using the software Geoscene3D, as a combined layer- and voxel model in order to enable the incorporation of the detailed structures encountered in the near-surface. The resulting geological model showed many details in the nearsurface, where the resolution of the data was highest, whereas the lower part appeared more homogeneous. A preliminary risk assessment of the Pillemark landfill, based on the novel 3D geological model, indicates potential impacts on the downgradient wetlands and creek. The deeper drinking water resource seems to be protected by a thick, continuous till unit that appeared massive without fractures. This will be further explored in an on-going study using the 3D geological model as a framework for a groundwater flow model of the 
1 Pillemark area. Contaminant concentrations in groundwater and downgradient surface water bodies will also

2 be considered in future risk assessments.

3

$4 \quad$ Acknowledgement

5 This study was supported by the research project GEOCON, Advancing GEOlogical, geophysical and

6 CONtaminant monitoring technologies for contaminated site investigation. The funding for GEOCON and the

7 studies in the Pillemark area are provided by Innovation Fund Denmark, the Technical University of Denmark

8 and Region of central Denmark. We thank the anonymous reviewers for their comments that helped strengthen

9 the paper.

10 


\section{References}

Auken, E., Christiansen, A. V., Kirkegaard, C., Fiandaca, G., Schamper, C., Behroozmand, A. A., Binley, A., Nielsen, E., Effers $\varnothing$, F., Christensen, N. B., Sørensen, K., Foged, N., and Vignoli, G., 2015, An overview of a highly versatile forward and stable inverse algorithm for airborne, ground-based and borehole electromagnetic and electric data.: Exploration Geophysics, v. 46, p. 223-235.

Barfod, A. A. S., Møller, I., and Christiansen, A. V., 2016, Compiling a national resistivity atlas of Denmark based on airborne and ground-based transient electromagnetic data: Journal of Applied Geophysics, v. 134, p. 199-209.

Barfod, A. A. S., Vilhelmsen, T. N., Jørgensen, F., Christiansen, A. V., Høyer, A.-S., Straubhaar, J., and Møller, I., 2018, Contributions to uncertainty related to hydrostratigraphic modeling using multiple-point statistics: Hydrology and Earth System Sciences, HESS, v. 22, p. 5485-5508.

Berkowitz, B., 2002, Characterizing flow and transport in fractured geological media: A review: Advances in Water Resources, v. 25, no. 8-12, p. 861-884.

Binley, A., and Kemna, A., 2005, DC resitivity and induced polarization methods, in Rubin, Y., Hubbard, S.S. ed., Hydrogeophysics, Springer, p. 129-156.

Bjerg, P. L., Tuxen, N., Reitzel, L. A., Albrechtsen, H.-J., and Kjeldsen, P., 2011, Natural attenuation processes in landfill leachate plumes at three Danish sites: Ground Water, v. 49, no. 5, p. 688-705.

Bockhorn, B., Møller, I., Klint, K. E. S., and Jensen, M. B., 2015, Geoelectrical mapping for improved performance of SUDS in clay tills: Environmental Earth Sciences, v. 74, p. 5263-5273.

Butt, T. E., Gouda, H. M., Baloch, M. I., Paul, P., Javadi, A. A., and Alam, A., 2014, Literature review of baseline study for risk analysis - The landfill leachate case: Envion. Int. , v. 63, p. 149-162.

Butt, T. E., Javadi, A. A., Nunns, M. A., and Beal, C. D., 2016, Development of a conceptual framework of holistic risk assessment - Landfill as a particular type of contaminated land: Sci. Total Environ., v. 569-570, p. 815-829. 
Butt, T. E., Lockley, E., and Oduyemi, K. O. K., 2008, Risk assessment of landfill disposal sites - State of the art: Waste Management, v. 28, p. 952-964.

Chambers, J. E., Kuras, O., Meldrum, P. I., Ogilvy, R. D., and Hollands, J., 2006, Electrical resistivity tomography applied to geologic, hydrogeologic, and engineering investigations at a former wastedisposal site: Geophysics, v. 71, no. B231-B239.

Chambon, J. C., Binning, P. J., Jørgensen, P. R., and Bjerg, P. L., 2011, A risk assessment tool for contaminated sites in low-permeability fractured media: Journal of Contaminant Hydrology, v. 124, p. 82-98.

Christensen, T. H., Kjeldsen, P., Bjerg, P. L., Jensen, D. L., Christensen, J. B., Baun, A., Albrechtsen, H.-J., and Heron, G., 2001, Biogeochemistry of landfill leachate plumes: Applied Geochemistry, v. 16, p. 659718.

Christiansen, A. V., and Auken, E., 2012, A global measure for depth of investigation: Geophysics, v. 77, no. 4, p. WB171-WB177.

Christiansen, A. V., Pedersen, J. B., Auken, E., Søe, N. E., Holst, M. K., and Kristiansen, S. M., 2016, Improved Geoarchaeological Mapping with Electromagnetic Induction Instruments from Dedicated Processing and Inversion: Remote sensing, v. 8, no. 12.

Dahlin, T., Bernstone, C., and Loke, M. H., 2002, A 3-D resistivity investigation of a contaminated site at Lernacken, Sweden: Geophysics, v. 67, no. 6, p. 1692-1700.

Dahlin, T., and Zhou, B., 2006, Multiple-gradient array measurements for multichannel 2D resistivity imaging: Near Surface Geophysics, v. 4, p. 113-123.

Doolittle, J. A., and Brevik, E. C., 2014, The use of electromagnetic induction techniques in soils studies: Geoderma, v. 223-225, p. 33-45.

Dumont, G., Robert, T., Marck, N., and Nguyen, F., 2017, Assessment of multiple geophysical techniques for the characterization of municipal waste deposit sites: Journal of Applied Geophysics, v. 145, p. 7483. 
Dumont, G., Robert, T., and Nguyen, F., 2018, Electrical resistivity tomography and distributed temperature sensing monitoring to assess the efficiency of horizontal recirculation drains on retrofit bioreactor landfills: Geophysics, v. 83, no. 2, p. B13-B23.

Ehlers, J., 1979, Fine Gravel Analyses after the Dutch Method as Tested out on Ristinge Klint: Bulletin of the geological society of Denmark, v. 27, p. 157-165.

Feyen, L., and Caers, J., 2006, Quantifying geological uncertainty for flow and transport modeling in multimodal heterogeneous formations: Advances in Water Resources, v. 29, no. 6, p. 912-929.

Fiandaca, G., Ramm, J., Binley, A., Gazoty, A., Christiansen, A. V., and Auken, E., 2013, Resolving spectral information from time domain induced polarization data through 2-D inversion: Geophysical Journal International, v. 192, p. 631-646.

Fitterman, D. V., and Stewart, M. T., 1986, Transient electromagnetic sounding for groundwater: Geophysics, v. 51, p. 995-1005.

Gazoty, A., Fiandaca, G., Pedersen, J., Auken, E., and Christiansen, A. V., 2012a, Mapping of landfills using time-domain spectral induced polarization data: The Eskelund case study: Near Surf. Geophys. , v. 10, p. 575-586.

Gazoty, A., Fiandaca, G., Pedersen, J., Auken, E., Christiansen, A. V., and Pedersen, J. K., 2012b, Application of time domain induced polarization to the mapping of lithotypes in a landfill site: Hydrol. Earth Syst. Sci., v. 16, no. 1793-1804.

Guérin, R., Munoz, M. L., Aran, C., Laperrelle, C., Hidra, M., Drouart, E., and Grellier, S., 2004, Leachate recirculation: moisture content assessment by means of a geophysical technique: Waste Management, v. 24, no. 8, p. 785-794.

Hansen, T. B., 2012, Pillemark Losseplads, 741-00001, Drift \& Montering.

He, X., Sonnenborg, T. O., Jørgensen, F., Høyer, A.-S., Møller, R. R., and Jensen, K. H., 2013, Analyzing the effects of geological and parameter uncertainty on prediction of groundwater head and travel time: Hydrology and Earth System Sciences, HESS, v. 10, p. 2789-2833. 
1 Houmark-Nielsen, M., 1987, Pleistocene stratigraphy and glacial history of the central part of Denmark: Bulletin of the Geological Society of Denmark, v. 36, p. 189.

,- 2007 , Extent and age of Middle and Late Pleistocene glaciations and periglacial episodes in southern Jylland, Denmark: Bulletin of the Geological Society of Denmark, DGF, v. 55, p. 9-35.

-, 2011, Pleistocene Glaciations in Denmark: A Closer Look at Chronology, Ice Dynamics and Landforms, in Ehlers, J., Gibbard, P. L., and Lughes, P. D., eds., Quaternary Glaciations - Extent and Chronology: A Closer Look Volume 15: Elsevier, Developments in Quaternary Science, p. 47-57.

Houmark-Nielsen, M., Krüger, J., and Kjær, K., 2005, De seneste 150.000 år i Danmark: Geoviden, v. 2, p. 1-

9

19.

Huysmans, M., and Dassargues, A., 2009, Application of multiple-point geostatistics on modelling groundwater flow and transport in a cross-bedded aquifer (Belgium): Hydrogeology Journal, v. 17, no. 8 .

Høyer, A.-S., Jørgensen, F., Sandersen, P. B. E., Viezzoli, A., and Møller, I., 2015, 3D geological modelling of a complex buried-valley network delineated from borehole and AEM data: Journal of Applied Geophysics, v. 122, p. 94-102.

Høyer, A.-S., Møller, I., and Jørgensen, F., 2013, Challenges in geophysical mapping of glaciotectonic structures: Geophysics v. 78, no. 5, p. B287-B303.

I-GIS, 2014, Geoscene3D: Aarhus, Denmark.

Jakobsen, P. R., Hermansen, B., and Tougaard, L., 2011, Danmarks digitale jordartskort 1:25000 Version 3.1 Danmark og Grønlands Geologiske undersøgelser rapport no.40: De nationale geologiske unders $\emptyset$ gelser for Danmark og Grønland.

Jørgensen, F., Møller, R. R., Nebel, L., Jensen, N.-P., Christiansen, A. V., and Sandersen, P. B. E., 2013, A method for cognitive 3D geological voxel modelling of AEM data: Bulletin of Engineering Geology and the Environment, v. 72, p. 421-432. 
Jørgensen, F., Sandersen, P. B. E., and Auken, E., 2003, Imaging buried Quaternary valleys using the transient electromagnetic method: Journal of Applied Geophysics, v. 53, no. 4, p. 199-213.

Kaufmann, O., and Martin, T., 2008, 3D geological modelling from boreholes, cross-sections and geological maps, application over former natural gas storages in coal mines: Computers and Geosciences, v. 34, p. $278-290$.

Keller, C. K., van der Kamp, G., and Cherry, J. A., 1986, Fracture permeability and groundwater flow in clayey till near Saskatoon, Saskatchewan: Canadian Geotechnical Journal, v. 23, no. 2, p. 229-240.

Klint, K. E. S., Abildtrup, C. A., Gravesen, P., Jakobsen, P. R., and Vosgerau, H., 2001, Sprækkers oprindelse og udbredelse i moræneler i Danmark: Vand og Jord, v. 8, no. 3, p. 111-119.

Klint, K. E. S., Møller, I., Maurya, P. K., and Christiansen, A. V., 2017, Optimising geological maping of glacial deposits using high-resolution electromagnetic induction data: Geological survey of Denmark and Greenland bulletin, v. 38, p. 9-12.

Klint, K. E. S., Nilsson, B., Troldborg, L., and Jakobsen, P. R., 2013, A Poly Morphological Concept for hydrogeological applications in heterogeneous glacial sediments. : Hydrogeology Journal, v. 21, no. 6, p. 1247-1264.

Kristensen, L., Juliusen, H., Christiansen, H. H., and Humlum, O., 2009, Structure and composition of a tidewater glacier push moraine, Svalbard, revealed by DC resistivity profiling: Boreas, v. 38, p. 176186.

Lelliott, M. R., Bridge, D. M., Kessler, H., Price, S. J., and Seymour, K. J., 2006, The application of 3D geological modelling to aquifer recharge assessments in an urban environment: Quaterly Journal of Engineering Geology and Hydrogeology, v. 39, p. 293-302.

Loke, M. H., Chambers, J. E., Rucker, D. F., Kuras, O., and Wilkinson, P. B., 2013, Recent developments in the direct-current geoelectrical imaging method: Journal of Applied Geophysics, v. 95, p. 135-156.

Madsen, L. M., Fiandaca, G., Christiansen, A. V., and Auken, E., 2017, Resolution of well-known resistivity equivalences by inclusion of time-domain induced polarization data: Geophysics, p. E47-E54. 
Madsen, V., 1897, Beskrivelse til det Geologiske Kort over Danmark. Kortbladet Sams $\varnothing$ : Danmarks Geologiske Undersøgelser, scale 1:20000.

Maio, R. D., Fais, S., Ligas, P., Piegara, E., Raga, R., and Cossu, R., 2018, 3D geophysical imaging for sitespecific characterization plan of an old landfill: Waste Management, v. 76, p. 629-642.

Maurya, P. K., Balbarini, N., Møller, I., Rønde, V., Christiansen, A. V., Bjerg, P. L., Auken, E., and Fiandaca, G., 2018, Subsurface imaging of water electrical conductivity, hydraulic permeability and lithology at contaminated sites by induced polarization: Geophysical Journal International, v. 213, p. 770-785.

Milosevic, N., Thomsen, N. I., Juhler, R. K., Albrechtsen, H.-J., and Bjerg, P. L., 2012, Identification of discharge zones and quantification of contaminant mass discharges into a local stream from a landfill in a heterogeneous geologic setting: Journal of Hydrology, v. 446-447, p. 13-23.

Møller, I., Søndergaard, V. H., Jørgensen, F., Auken, E., and Christiansen, A. V., 2009, Integrated management and utilization of hydrogeophysical data on a national scale: Near Surface Geophysics, v. 7, no. 5-6, p. 647-659.

Olsson, P.-I., Fiandaca, G., Larsen, J. J., Dahlin, T., and Auken, E., 2016, Doubling the spectrum of timedomain induced polarization by harmonic de-noising, drift correction, spike removal, tapered gating and data uncertainty estimation: Geophysical Journal International, v. 207, p. 774-784.

Pellerin, L., 2002, Applications of Electrical and Electromagnetic Methods for Environmental and Geotechnical Investigations: Surv. Geophysics, v. 23, p. 101-132.

Pelton, W. H., Ward, S. H., Hallof, P. G., Sill, W. R., and Nelson, P. H., 1978, Mineral discrimanation and removal of inductive coupling with multifrequency IP: Geophysics, v. 43, p. 588-609.

Piotrowski, J., and Tulaczyk, S., 1999, Subglacial conditions under the last ice sheet in northwest Germany: ice-bed separation and enhanced basal sliding Germany? : Quaternary Science Reviews v. 18, p. 737 $-751$. 
Pirot, G., Renard, P., Huber, E., Straubhaar, J., and Huggenberger, P., 2015, Influence of conceptual model uncertainty on contaminant transport forecasting in braided river aquifers: J. Hydrol. , v. 531, p. $124-141$.

Refsgaard, J. C., Christensen, S., Sonnenborg, T. O., Seifert, D., Højbjerg, A. L., and Troldborg, L., 2012, Review of strategies for handling geological uncertainty in groundwater flow and transport modeling: Advances in Water Resources, v. 36, p. 36-50.

Revil, A., Karaoulis, M., Johnson, T., and Kemna, A., 2012, Review: Some low-frequency electrical methods for subsurface characterization and monitoring in hydrogeology: Hydrogeology Journal, v. 20, p. 617-658.

Robins, N. S., Davies, J., and Dumpleton, S., 2008, Groundwater flow in the South Wales coalfield: historical data informing 3D modelling: Quaterly Journal of Engineering Geology and Hydrogeology, v. 41, p. 477-486.

Sørensen, K. I., Auken, E., Christensen, N. B., and Pellerin, L., 2005, An Integrated Approach for Hydrogeophysical Investigations: New Technologies and a Case History, in Butler, D. K., ed., NearSurface Geophysics, Society of Exploration Geophysicists, p. 585-606.

Thomsen, N. I., Milosevic, N., and Bjerg, P. L., 2012, Application of a mass balance method at an old landfill to assess the impact on surrounding water resources: Waste Management, v. 32, p. 2406-2417.

Troldborg, M., Nowak, W., Tuxen, N., Bjerg, P. L., Helmig, R., and Binning, P. J., 2010, Uncertainty evaluation of mass discharge estimates from a contaminated site using a fully Bayesian framework: Water Resour. Res., v. 46, no. W12552.

Ustra, A. T., Elis, V. R., Mondelli, G., Zuquette, L. V., and Giacheti, H. L., 2012, Case study: a 3D resistivity and induced polarization imaging from downstream a waste disposal site in Brazil: Environmental Earth Sciences, v. 66, p. 763-772.

Viezzoli, A., Christiansen, A. V., Auken, E., and Sørensen, K., 2008, Quasi-3D modeling of airborne TEM data by spatially constrained inversion: Geophysics, v. 73, no. 3, p. F105-F113. 
1 Wycisk, P., Hubert, T., Gossel, W., and Neumann, C., 2009, High-resolution 3D spatial modelling of complex geological structures for an environmental risk assessment of abundant mining and industrial megasites: Computers and Geosciences, v. 35, no. 1, p. 165-182.

4

5

6

7

8

9

10

11 